\title{
Induction and repetitive embryogenesis of Ocotea porosa
}

\author{
Marguerite Quoirin ${ }^{*}$, Luciana Pelegrini ${ }^{2}$, Luciana Ribas $^{2}$ \\ From IUFRO Tree Biotechnology Conference 2011: From Genomes to Integration and Delivery \\ Arraial d'Ajuda, Bahia, Brazil. 26 June - 2 July 2011
}

\begin{abstract}
Introduction
Ocotea porosa (Liberato Barroso) known as "imbuia" belongs to the Lauraceae family and is native to the Mixed Ombrophilous Forest (Araucaria Forest) where it was heavily exploited due to the high quality and worldwide value of his hardwood that is exported in large quantities for luxury furnishing manufactures [1]. The sexual propagation of $O$. porosa at its natural occurrence area is difficult, due to the strong tegumentary dormancy and its irregular germination. Moreover, the seed viability is short by virtue of being a recalcitrant species, showing high level of humidity [1]. Another limiting factor for its vegetative propagation is the low response of cuttings to the induction of adventitious roots (4\%) [2]. The aim of this study was to establish repetitive cycles of secondary somatic embryogenesis from $O$. porosa embryonic axes.
\end{abstract}

\section{Material and methods}

Zygotic embryonic axes from immature seeds were used as explants. The seed disinfestation was performed in a laminar flow chamber, through immersion in ethanol $70 \%(\mathrm{v} / \mathrm{v}$ ) for $5 \mathrm{~min}$, followed by $20 \mathrm{~min}$ in $\mathrm{NaOCl} 4 \%$ $(\mathrm{v} / \mathrm{v})$ supplemented with $0,1 \%$ of Tween ${ }^{\circledR} 20$. After that, the seeds were rinsed five times with sterile water. The WPM [3] culture medium was used in all stages. Embryonic axes were inoculated on culture medium supplemented with sucrose $\left(20 \mathrm{~g} \mathrm{~L}^{-1}\right)$, activated charcoal $\left(1.5 \mathrm{~g} \mathrm{~L}^{-1}\right)$, agar $\operatorname{Vetec}^{\circledR}\left(4 \mathrm{~g} \mathrm{~L}^{-1}\right)$ and2,4-D $(200 \mu \mathrm{M})$ combined or not with hydrolyzed caseinor glutamine $\left(0.5\right.$ or $\left.1 \mathrm{~g} \mathrm{~L}^{-1}\right)$ during 90 days. The somatic embryos obtained in the induction phase were multiplied on medium with sucrose $\left(20 \mathrm{~g} \mathrm{~L}^{-1}\right)$, agar Vetec ${ }^{\circledR}\left(3.5 \mathrm{~g} \mathrm{~L}^{-1}\right)$ and 2,4-D $(22.62 \mu \mathrm{M})$ combined with 2-iP $(2.46 \mu \mathrm{M})$ for

\footnotetext{
*Correspondence: mquoirin@ufpr.br

'Universidade Federal do Paraná, Brazil

Full list of author information is available at the end of the article
}

90 days followed by transfer to culture medium with $0.5 \mathrm{~g} \mathrm{~L}^{-1}$ of hydrolyzed casein combined with $0.5 \mathrm{~g} \mathrm{~L}^{-1}$ glutamine or $1 \mathrm{~g} \mathrm{~L}^{-1}$ hydrolyzed casein or $1 \mathrm{~g} \mathrm{~L}^{-1}$ glutamine for 30 days. The maturation of somatic embryos was tested in WPM culture medium containing sucrose $\left(20 \mathrm{~g} \mathrm{~L}^{-1}\right)$, agar Vetec ${ }^{\circledR}\left(3.5 \mathrm{~g} \mathrm{~L}^{-1}\right)$ and polyethylene glycol (PEG 6000) (control, 3.5 and 7\%) during 30 days. The experiment was repeated twice. All the cultures were maintained in the dark at $27 \pm 2^{\circ} \mathrm{C}$ (day) and $18 \pm 2^{\circ} \mathrm{C}$ (night).

\section{Results and discussion}

Patterns of direct and indirect induction of somatic embryos were observed with low frequency in culture medium containing $200 \mu \mathrm{M}$ 2,4-D alone or combined with $1 \mathrm{~g} \mathrm{~L}^{-1}$ hydrolyzed casein or glutamine. The mean percentage of calli with somatic embryos varied between $4.2 \%$ and $8.3 \%$ for primary somatic embryogenesis without differences between treatments (after 90 days). In the present study, the maximum percentage of somatic embryos induction was $8.3 \%$. Similar results were found with $O$. odorifera that presented a mean percentage of $6.5 \%$ [4]. On the culture medium containing $200 \mu \mathrm{M}$ 2,4-D, the percentage of calli with somatic embryos was $6.3 \%$ and the formation of one globular embryo was visible. When 200 $\mu \mathrm{M}$ 2,4-D was combined with $1 \mathrm{~g} \mathrm{~L}^{-1}$ hydrolyzed casein this percentage was $8.3 \%$ and two globular somatic embryos were developed per callus. However, in the medium containing $200 \mu \mathrm{M} 2,4-\mathrm{D}$ and $1 \mathrm{~g} \mathrm{~L}^{-1}$ glutamine, after 90 days the percentage was smaller (4.2\%) and two globular and one cordiform shape embryos were observed. After three months, the primary somatic embryos subculturedin culture media without plant growth regulators with or without activated charcoal did not progress to torpedo and cotyledonary stages. In repetitive embryogenesis the combination of $0.5 \mathrm{~g} \mathrm{~L}^{-1}$ of hydrolyzed casein and glutamine promoted an average of 46.6 new globular embryos

C 2011 Quoirin et al; licensee BioMed Central Ltd. This is an open access article distributed under the terms of the Creative Commons 
per callus and $75 \%$ of callus presented embryogenic mass com pro-embryos. The subculture in media containing $1 \mathrm{~g} \mathrm{~L}^{-1}$ hydrolyzed casein promoted an average formation of 58 globular embryos, 2 cordiform, 2.5 torpedo and 1 cotiledonary per callus at the end of every subculture and $72.5 \%$ of explants formed mass containing proembryos. When $1 \mathrm{~g} \mathrm{~L}^{-1}$ glutamine was added into the media, $57.5 \%$ of the mass presented pro-embryos and the induction of globular somatic embryos was lower (23.3 globular embryos per explant). During maturation phase, the somatic embryos develop from initial to late stages. However, in the present conditions of maturation, the percentage of embryos developing to cordiform, torpedo and cotyledonary ontogenetic stages was low, revealing an asynchronous development. In both treatments (3.5 and $7 \%$ PEG) as well as in the control, the first response was the formation of pro-embryogenic masses in $100 \%$ of calluses. In the control and in the medium supplemented with 3.5\% PEG, an average of 32.7 and 27 new globular embryos were formed per explant, respectively. When PEG concentration in culture medium was 7\%, the formation of new globular embryos decreased (12.7), but the development of cordiform (1.5), torpedo (2) and cotyledonary embryos (2) was observed.

Author details

'Universidade Federal do Paraná, Brazil. ${ }^{2}$ UFPRm Brazil.

Published: 13 September 2011

\section{References}

1. Carvalho PER: Espécies arbóreas Brazileiras. Colombo: Embrapa Florestas; 2003:1:1040

2. Inoue MT, Putton V: Macropropagação de 12 espécies arbóreas da Floresta Ombrófila Mista. Floresta 2007, 37:55-61.

3. Lloyd G, McCown B: Commercially feasible micropropagation of mountain laurel, Kalmia latifolia, by use of shoot tip culture. Proceed Int Plant Propagation Soc 1980, 30:421-427.

4. Santa-Catarina C, Maciel SC, Pedrotti EL: Germinação in vitro e embriogênese somática a partir de embriões imaturos de canela sassafrás (Ocotea odorifera Mez). Revista Brazileira de Botanica 2001, 24:501-510.

doi:10.1186/1753-6561-5-S7-P148

Cite this article as: Quoirin et al: Induction and repetitive embryogenesis of Ocotea porosa. BMC Proceedings 2011 5(Suppl 7):P148.

\section{Submit your next manuscript to BioMed Central} and take full advantage of:

- Convenient online submission

- Thorough peer review

- No space constraints or color figure charges

- Immediate publication on acceptance

- Inclusion in PubMed, CAS, Scopus and Google Scholar

- Research which is freely available for redistribution

Submit your manuscript at www.biomedcentral.com/submit
C Biomed Central 